\title{
Reconstructing multiculturalism Social categorizations challenged in the Förskolan Rävlyan and Tatu and Patu series
}

\begin{abstract}
In this article, representations of multiculturalism in Swedish and Finnish picturebooks are examined through the Förskolan Rävlyan and Tatu and Patu series. In the article, multiculturalism is understood and studied with an intersectional approach. This means considering sociocultural categorizations such as ethnicity, gender, nationality and disability to be meaningful to the existing social, political and economic structures of societies. These categorizations are seen to have the power to reproduce and circulate dominant discourses that effect the social inclusion and exclusion of certain groups of people. Thus, the social categories are examined as performative textual discourses, meaning that texts are acknowledged to be not only reflecting, but also creating social reality. Both series present diversity as an integrated part of the story by means of non-explicit multiculturalism. The analysis reveals that both series of books contain representations of $d i$ versity that can challenge some possibly exclusive social categorizations, such as nationality. In conclusion, these books can be seen to be progressive in their attempts to promote a transformative understanding of today's Nordic societies.
\end{abstract}

Keywords: Diversity, Intersectionality, Multiculturalism, Performativity theory, Swedish picturebooks, Finnish picturebooks, Siv Widerberg, Aino Havukainen, Sami Toivonen

Both Finnish and Swedish children's literature have a history of addressing societal phenomena. In Sweden, the politicised literary climate in the 1960s started to affect children's literature as themes related to racial discrimination and cultural clashes appeared in books for children (B. Westin 36). Boel Westin writes that the function of children's books "was to question reality and furnish information about international and social problems" (36). Wars and conflicts 
(e.g. the collapse of the Soviet Union, 1991 and the Yugoslav Wars, 1991-1999) affected these countries' political climate and public opinion, and increased the number of asylum seekers. In the 1990's, Sweden received a large number of refugees and asylum seekers, while the flow to Finland started later and was smaller in volume. ${ }^{1}$ In Finnish children's literature, the theme of tolerance became more emphasised in the 1980s and this also continued in the 1990s, as the public debate about growing immigration took off in Finnish society. During the first decade of the 21st century, representations of a more diverse society increased slightly in Finnish picturebooks (Pesonen, "Nationality"; "Xing, Sikuriina, Tatu ja Patu"), though many topics related to diversity, for example human rights issues and refugees, never became really common (Heikkilä-Halttunen 126-127). In Sweden, however, during the past years, the topic of ethnicity in children's books, as well as in other cultural products, like movies, has been discussed rather intensively. One debated case is the Lilla Hjärtat (Little Heart) character by Stina Wirsén, which brought about discussions on political correctness and artistic freedom, and reminded us how we cannot free ourselves from the historical contexts of racism (see e.g. Österlund). The debates have made Swedish authors and illustrators more aware of these issues, but even if ethnic diversity is discussed and also present in today's Swedish picturebooks, a recent study by The Swedish Institute for Children's Books shows that only few picturebooks feature dark skinned children as their main characters ("Bokprovning" 9).

Based on the above notions, this article asks: how is diversity represented in the Förskolan Rävlyan and the Tatu and Patu series? Diversity is seen as a wide concept including ethnicity, gender, nationality, age and dis/ability, however, the focus here is more on representations of nationality and ethnicity. The article also examines if the representations of diversity in these two series of books can challenge the dominant sociocultural categorizations that produce and reproduce unequal power relations between ethnic/cultural majorities and minorities through the ways in which they represent things and position people. Thus questions in relation to tolerance and difference are also discussed.

\section{The Förskolan Rävlyan and the Tatu and Patu series}

The data analysed is selected from a broad range of Swedish and Finnish children's literature. This article is part of an on-going $\mathrm{PhD}$ research in which I have studied more than 200 Finnish books fo- 
cusing on multiculturalism and/or nationality. Also Swedish children's literature with representations of multiculturalism was examined at length. For the present article, five books are selected for closer examination, the criterion being that they should present diversity through means of non-explicit multiculturalism. Thus these books represent only a small portion of picturebooks from both countries. The selected picturebooks published in Finland belong to the highly popular Tatu and Patu series: Tatu ja Patu työn touhussa (Tatu and Patu Go to Work, 2006), Tatu ja Patu päiväkodissa (Tatu and Patu at the Kindergarten, 2006) and This is Finland (2007) by Aino Havukainen and Sami Toivonen. From the Swedish picturebooks Ojdå! (Oh Dear!, 2009) and Kolla! (Look!, 2009)2 from the series Förskolan Rävlyan (Kindergarten Fox Earth) by Siv Widerberg, illustrated by Cecilia Torudd, were chosen for closer examination.

The writers of both series have produced various books for children in which diversity is part of the story. Siv Widerberg wrote books already in the 1960s dealing with issues related to diversity. In her books, especially in the Daghemmet Rödmyran (Kindergarten Red Ant) series consisting of four books published in 1982, she introduced a very diverse group of children. ${ }^{3}$ Widerberg herself states in the "Foreword for adults" in the Förskolan Rävlyan series that she wanted to show an ordinary day at an ordinary kindergarten. Widerberg adds that she prefers to show the collective aspect, rather than draw attention to any specific protagonists. In the research literature, Siv Widerberg is said to examine questions related to companionship and a common cause (B. Westin 40). Just like Widerberg, the creators of the Tatu and Patu series (Aino Havukainen and Sami Toivonen) depict diversity in society in their other stories too. One example of this is the Veera series; however, diversity is not as clearly manifest as in Widerberg's books. It is also worth noticing that diversity is part of several books in the Tatu and Patu series (e.g. Tatu and Patu's Oddball Bedtime Book, 2010 and Tatu and Patu as Superheroes, 2010), in which the illustrations, as well as the texts deal with diverse nationalities, ethnicities and gender roles. However, diversity is not a central theme in these books.

\section{An intersectional approach to sociocultural categorizations}

In this article, I will make use of performativity theory when looking at representations of diversity in order to gain a broad understanding of diverse sociocultural categorisations. My understanding of sociocultural categorization comes from the theory of intersectionality; 
that is, seeing these categories interacting and producing (in many cases) unjust social relations (see e.g. McCall). Thus, the sociocultural categorizations are seen as existing in, as well as reproducing, the social, political and economic structures of societies. This is due to the power of these social division to legitimize social exclusion and inclusion (see e.g. Crenshaw; McCall; Österlund, Lassén-Seger, and Franck). Hence, in this analysis, I take into consideration the different categories in order to see if they are interwoven and how, and also whether the traditional understanding of them can be challenged in these books. Though, as mentioned in the beginning, the focus is more in representations of ethnicity and nationality. These specific sociocultural categories still often dominate the public discussions about multiculturalism. Especially in Finland, the dominant discourses of multiculturalism often refer to refugees and immigration (Lehtonen and Löytty 7).

The analysis is carried out via close reading with an understanding of texts not only as reflections of social reality, but more importantly, as a factor that has the capacity to produce, as well as change reality. Consequently, a literary study can be considered as a study of social change (see Botelho and Kabakow Rudman). Therefore the books analysed here are considered as possibly having transformative power. Jo Lampert explains this transformative power by arguing that language in all of its forms not only represents who we are, but "plays a significant part in how we become our selves" (58).This means taking into consideration what Judith Butler argues: "performative is that discursive practice that enacts or produces that which it names" (13). Although Butler's writings about "the power to produce - demarcate, circulate and differentiate" (13) are founded on the performativity of gender and sex, they have also been adapted to other social categorisations, such as ethnicity or nationality (see e.g. Lambert 58).

In textual analysis, according to John Stephens, multiculturalism as non-explicit is detected as a strategy to reduce the manifestations of Otherness in portraying minority groups. In addition, critical theories such as anti-racism theory and queer theory provide a valuable perspective when examining the representations of diversity, as they interrogate the existing order of power, including the issues of normativity (Nikolajeva 7). In this article, anti-racism refers to those forms of thought and practice that aim to make racism visible, and also aim to eradicate it (e.g. Bonnet 4). Evidently, examining changing representations of diversity in society is important in the globalising world; however, contemporary research should also investigate how 
children's literature has evolved historically in respective countries. According to my own research on children's books in Finland, the patronising and exoticizing of the Other was previously quite a common phenomenon (Pesonen, "Nationality"; "Etnisen erilaisuuden kuvauksia"); just like Maria Nikolajeva has indicated, "the common stereotype of socialising the savage" (103) has occurred rather extensively in cultural products - including children's literature. Though the portrayal of gender and ethnic groups is more varied in contemporary literature, the stereotypical portraits tend even today to be recurring images in children's literature (Harlin and Morgan 187).

\section{Representations of diversity in the Förskolan Rävlyan and Tatu and Patu series}

The Förskolan Rävlyan, is a realistic picturebook series by Siv Widerberg, represents a diverse set of characters. Both books, Ojdå! (2009), and Kolla! (2009) begin with the same double-page illustration (picture 1) which depicts children in their daily activities, playing and having fun, but also quarrelling and needing to cope with their own emotional upheavals.
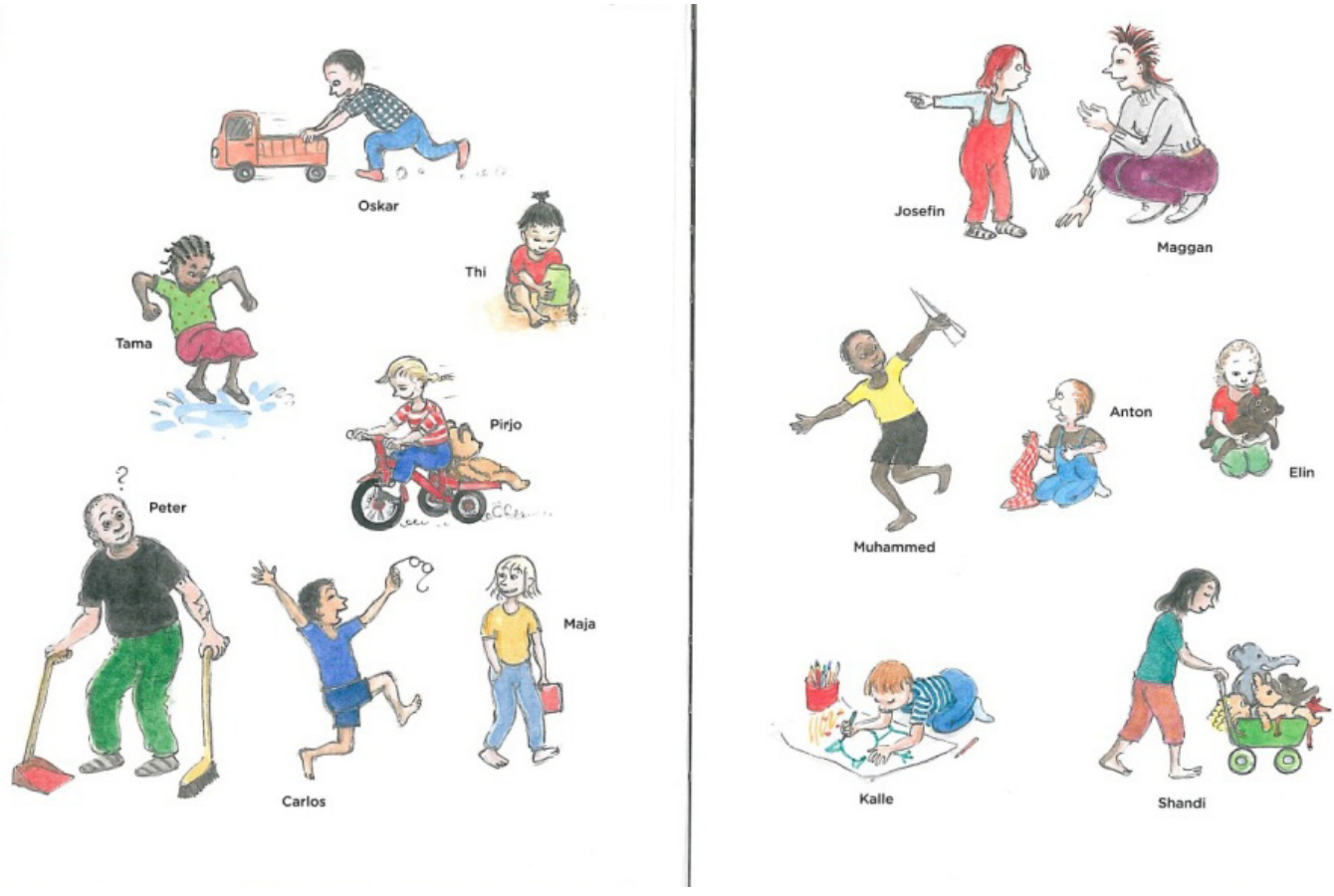

Picture I. Ojdå! (2009, n.pag.). Text by Siv Widerberg and illustrations by Cecilia Torudd. Eriksson \& Lindgren: Stockholm. 
Ojdå! (2009) shows a good example of non-explicit multiculturalism: children's ethnic background is not even mentioned. However, when children's names and their physical appearance are examined more carefully, it is obvious that different ethnicities are represented in the portrait gallery, including not only Europeans but also people of Asian, African and Indian origin. In the other Swedish book Kolla! (2009), the same children from the kindergarten make an excursion into a forest, yet the story is more multi-layered than that. Children's emotions, jealousy for example, play a notable role in both Ojdå! and Kolla! The protagonist in Kolla! is Oskar, whose behaviour reveals the jealousy he feels towards his new baby sister. Collectively, the other children persuade Oskar to join them for the excursion to the forest. Finally, the kids end up playing a game together looking for sticks from the forest which would resemble the initial letters of their respective names.

All in all, in the Förskolan Rävlyan books the main theme is not ethnicity but something else: collective identification, mutual learning and the like. This I consider as a sign of non-explicit multiculturalism, since it is in line with Stephens' arguments in Schemas and Scripts about the importance of illustrations in demonstrating "variables of ethnicity, class, age, and dress preferences" (16). Stephens continues that presenting a team as a heterogeneous group working for a common goal produces representations of class and ethnicity as "normal variables" (ibid.). Hence, the narrative does not reproduce ethnic and racial hierarchies. In Ojdå!, the presentation of a heterogeneous kindergarten group with identifiable human emotions such as Oskar's apparent jealousy towards his baby sister, helps to create a realistic picture of society with all its diversity. Presenting all of the characters, children and adults alike, as individuals with specific personalities, without highlighting the differences, functions as an anti-racist strategy. This kind of strategy can also function as a mode of normalising diversity, when the purpose is to make the readers aware of prejudice and injustice in society (see also Pesonen, "Anti-racist Strategies").

The series featuring Tatu and Patu by Aino Havukainen and Sami Toivonen is enormously popular in Finland. I shall discuss three books from this series (with a total of 12 books); first Tatu and Patu take us to a Finnish kindergarten, after which they introduce us to Finnish work life. The third book discussed is This is Finland (2007). In Tatu and Patu at the Kindergarten (Tatu ja Patu päiväkodissa, 2004, translated into 8 different languages), we meet the two brothers from Outola (Oddsville), who are not familiar with all of the 
norms and customs of the surrounding community, which causes hilarious misunderstandings and comic situations. This is exactly the humour and absurd situations that describe the whole series; hence, the Tatu and Patu series could be described as slapstick, or as postmodern picturebooks, since the ironical questioning of the relationship between fiction and reality is a central part of the stories (cf. Arizpe 69).

In Tatu and Patu at the Kindergarten (2004) the brothers accidentally end up in a kindergarten and happily join the children in their daily activities. The story has a rather similar orientation towards diversity in society as the Förskolan Rävlyan series. In the pictures, we can see children with diverse ethnic, age and gender features. Diversity is presented without underlining, or even mentioning it, which again is a sign of non-explicit multiculturalism. In all of the books in this series, the slightly odd-looking brothers, Tatu and Patu, are the protagonists, but the books introduce several other characters too. In Tatu and Patu at the Kindergarten there are also Laura, Niko and Oona, who represent ethnic, gender and age differences.

Another book from this series is Tatu and Patu at Work (Tatu ja Patu työn touhussa, 2006, translated into 11 languages), in which the brothers decide to learn about different jobs. They explore the work of a baker, hairdresser, journalist, nurse, farmer and a cleaner, among other jobs. Once again, non-explicit multiculturalism is manifest in diverse ethnic and gender presentations (see also picture 2); additionally, social class differences are handled with sensitivity. All occupations are depicted as equally important and respectable, the jobs of the cleaners, carpenters, office secretaries, teachers and journalists are all introduced as desirable options in work life.

Just like in the other books examined here, Tatu and Patu at Work demonstrates multiple gender roles. This is true of Ojdå! too, as there is a female janitor called Harriet working at the kindergarten. Tatu and Patu at Work is particularly interesting in terms of gender roles when looking at the presentations of those jobs that have traditionally been associated with men or women. In the story, there are no male and female jobs; instead, a woman is depicted as a machinist, and a man as a hospital nurse and so forth. When gender is structured in social institutions (Andersen and Hill Collins 67), the representations of women in traditionally masculine professions (e.g. as janitors) can be read as reconstructions of socially constructed categories. Admittedly, researchers of children's literature have been studying representations of gender roles for decades (see. e.g. Stephens, "Preface"), yet I find it very relevant to reinvestigate the 


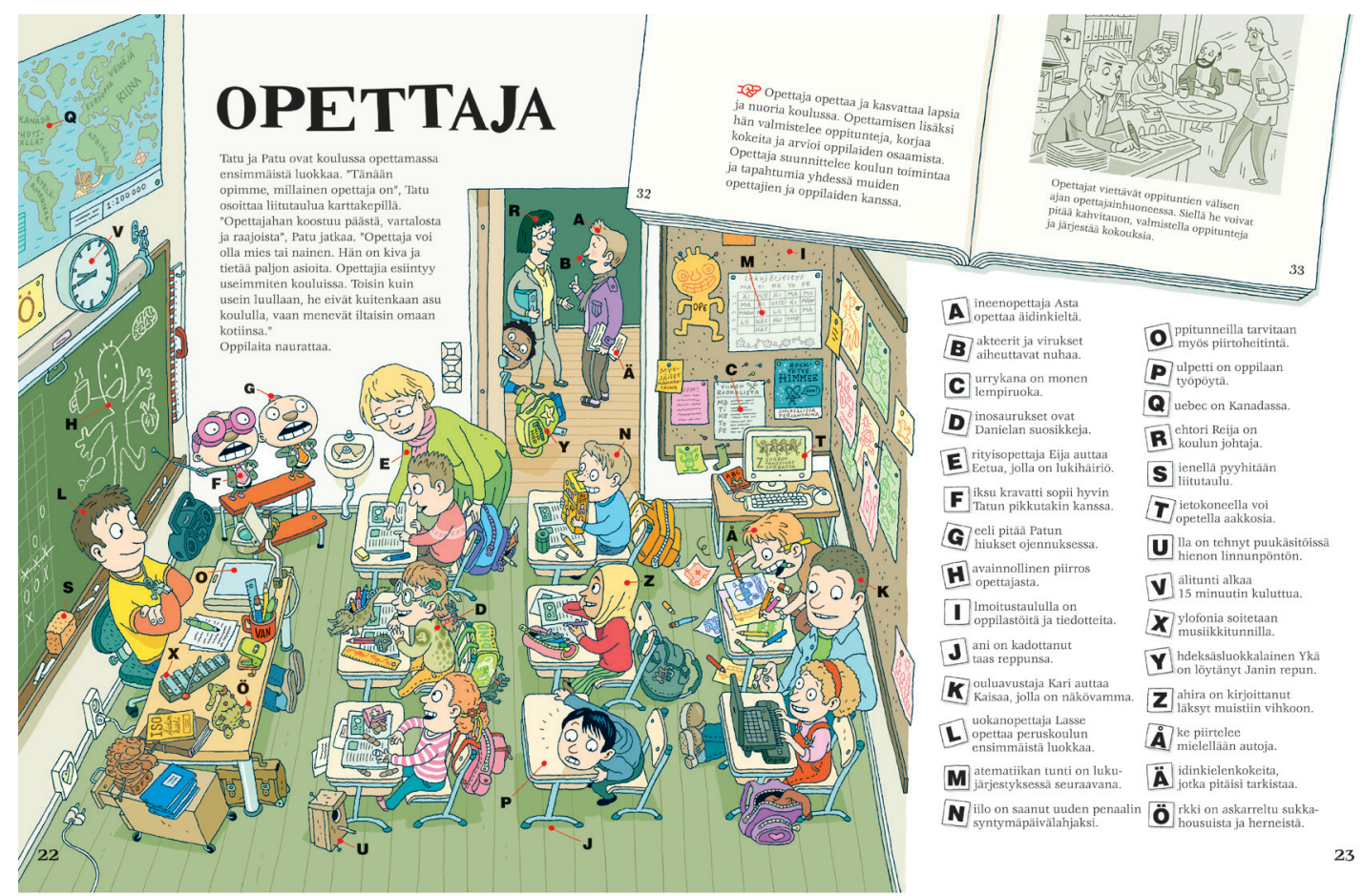

Picture 2. Tatu ja Patu työn touhussa. (2006, 22-23) Text and illustration by Aino Havukainen and Sami Toivonen. Helsinki: Otava

diverse representations of gender especially when they are intertwined with other social categories, reminding us of the multiplicity and complexity of these categories.

Picture 2 introduces the teacher and a very heterogeneous group of pupils busily working in the classroom. In the text (the letters of the alphabet listed on the side) the letter $\mathrm{Z}$ says: "Zahira has written down the homework in a notebook" (23). Religious diversity is depicted here in the form of a headscarf which Zahira is wearing. The letter Y says: "Ykä the $9^{\text {th }}$ grader has found Jani's backpack" (23). Ykä, whose skin colour is not mentioned in the texts, is seen at the door peeping into the classroom. Diversity related to dis/ability is represented in the classroom by two students, Eetu and Kaisa. Eetu has learning difficulties and is therefore helped by a special education teacher, and Kaisa who is visually impaired is helped by a school assistant. Dis/abilities are most often represented in children's stories in a normative way; that is, educating about differences, which can, despite good intensions, appear patronising. At times, this is due to the over-emphasised morality of the books (cf. Pesonen, "Na- 
tionality"; Hollindale). Here, similarly to the above discussion on Förskolan Rävlyan, due to the dual mode of picturebooks, the social differences are represented only in illustrations, without addressing them in texts. In both series, but especially in the Tatu and Patu books, the illustration does not only portray and correspond symmetrically to what we learn from the text, but provides a more complicated narrative full of details. Hence, the two series could be described as expanding picturebooks (see Nikolajeva and Scott 11-15).

In both series studied here, it is through illustration that the traditional social categorizations are challenged. This is done by presenting all the children as active agents, which again means that some special differences (e.g. ethnicity or disability) are by no means emphasised. In these two series, nationality is one of the categories which is not emphasised in texts at all, thus the diverse representations of ethnicities can be seen to produce a more inclusive understanding of nationality as a social category. Thus, considering language being performative, the inclusive representations of all children can be seen to further challenge some of the dominant discourses related to multiculturalism. As discussed also earlier, in public discussions multiculturalism is still often connected to differences between 'us and them' (see e.g. Lehtonen and Löytty).

One of the authors who underlines the importance of presenting diversity in society in children's books is Liz Laycock (85-87), who writes about linguistic diversity in children's literature. Referring to Ahlberg's Starting School (1988), Laycock claims that presenting the daily routines in a multicultural classroom realistically makes it easy for children to relate to it. Laycock also draws attention to "books written to a 'multiethnic' brief", which she claims to be a tokenistic act of writing (87). As shown above (picture 1 and 2), in Förskolan Rävlyan and in the Tatu and Patu series, the characters with various different ethnicities are not shown only as minor characters in the background, but as active individuals with names and personalities. My point is precisely this: neither of the analysed series deploy any token characters of any minorities, that is, there are no stereotypical characters included in the story only for the book to appear multicultural, or to make the story more liberal-minded or politically correct.

With reference to Laycock and language diversity, it is detectable in another Tatu and Patu book, This is Finland (2007, 22-23). Though the book is about Finland, it does not slip into representing stereotypical matters about Finns or about the country, which could reinforce a fixed idea about Finnish nationality. On the contrary, when the official languages of Finland are introduced, this means the 
Finnish language, but also the other official language, Swedish, and in addition, the Sami language, being one of the minority languages in Finland. In addition, representing diversity of those speaking different languages and dialects, serves as a reminder that there is always diversity inside, even within groups of people who are considered as highly homogeneous in nature, such as speakers of certain languages.

Furthermore, This is Finland (2007) covers also "the everyday life of Finns in the $21^{\text {st }}$ century" (37); diverse family units, different age groups, as well as people with different ethnic backgrounds are presented as an ordinary part of a contemporary society. These examples in relation to multiple languages, as well as diverse representations of population in Finland demonstrate to the readers that there are no groups in society that are completely homogenous; instead, these groupings always consist of individuals who are all different in many respects. Karen Sands-O'Connor (419) has claimed in a similar manner that we need "more natural presentations" of multiculturalism in relation to multiracial families. She demands that the emphasis on difference "must be, if not erased, at least subdued and balanced" (419).

\section{Tatu and Patu and Förskolan Rävlyan challenging social categorizations?}

The books analysed in this article introduce diverse characters, children and adults alike, as individuals with specific personalities, without highlighting the differences. Presenting diverse groups of children and emphasising the commonality of their actions can be taken as an anti-racist strategy with the intention to remind the readers of the diversity of today's societies. Thus, when sociocultural categorizations based on ethnicity, nationality, gender, or dis/ ability are not brought to the foreground, the exclusion/belonging division does not result in separating people as strongly into ' us and them'. In both series, the representations of heterogeneous groups of characters create a picture of a more diverse society in which individuals belong to a variety of categories that might be overlapping, even contradictory.

The overlapping of sociocultural categorizations is present in, for example, This Is Finland (38-39), where we meet a Finnish-Swedish couple, Ingrid and Thomas Lagerlöf, who are also pensioners, and as a single mother, Leena Aaltonen, who has an adopted daughter. In these representations, age, ethnicity, language and untraditional fa- 
mily model blend together, and hence narrate about the complexity of cultural diversity. Thus individuals are not reduced to represent only one often fixed category based on their nationality, gender or other sociocultural division.

In addition, This is Finland challenges the patriotic and exclusive understanding of Finnishness rather directly when in the last double-page Tatu and Patu are shown in the sauna: "'Thank goodness we've finally gotten to the bottom of being Finnish!' Tatu exclaims. 'When in Helsinki...' 'Well said!' Patu declares." (45). The textual narrative could be read as very nationalistic and supporting an exclusive view of Finnishness, however the illustration challenges this verbal message by offering contradicting meanings. In the illustration, Tatu and Patu are shown to have understood even the basics of the Finnish sauna wrong (e.g. burning Nokia phones in the stove and wearing skis while in sauna). Thus the reader is encouraged to question what "being Finnish" means and who can decide this. It is precisely through the contradiction between the visual and the textual narratives, that the traditional meanings of cultural symbols can be questioned.

All five books introduced here portray ethnically diverse groups of characters, which could be taken as a sign of colour-blindness due to the unspecified ethnic backgrounds; that is, seemingly not recognising the significance of 'race', or any other social categories (Andersen and Hill Collins). However, I suggest that the presentation of all of the children as highly active agents with developing and well-rounded characters (see e.g. Nikolajeva) ultimately produces representations of non-explicit multiculturalism. In these specific books, diversity is shown to be part of modern-day Swedish and Finnish societies. However, this is done so that none of the children or adults become the odd one out, as no-one's differences are highlighted more than anyone else's. Although in the Tatu and Patu series, the two brothers are the 'odd ones', as they come from Outola (Oddsville) and thus are not familiar with all of the norms and customs of the surrounding community, they are not in any way excluded. The different viewpoints that these brothers bring forward enable them, as well as the reader, to question the commonalities, which otherwise often are presented as platitudes.

According to Margaret Andersen and Patricia Hill Collins people's exclusionary actions, based on racist and sexist beliefs, can exist because they do not know any better; consequently, to challenge oppressive behaviour, for example, in gender relations, requires a reconstruction of knowledge. Clearly, the intention of these stories 
is to teach about diverse societies without reinforcing the existing understandings of different categorizations. The books do not settle on merely teaching the acceptance of others, which occasionally happens when anti-racist messages are written into children's literature (see Pesonen, "Anti-racist Strategies"). According to my analysis, anti-racism includes here the ideas of denaturalizing and problematizing taken-for-granted assumptions about human differences. Thus, the representations which normalize diversity can be read as challenging the dominant discourses in relation to 'difference' and 'normal'. This can be understood as a form of didacticism in children's literature, as it contains transformative potential. Children's literature, when presenting social categories without emphasising differences, can challenge normative assumptions of people. Thus, books can have an input in transforming people's understanding of sociocultural categorizations. From this analysis, I agree with Jackie C. Horne who has argued that the values that promote social justice should be more present in children's literature, including the discussion of power and privilege in existing social, political and economic structures.

\section{Conclusion}

Based on the analysis, presenting diversity in society as an integrated and evident part of the story even contributes to moral education. This again means taking the differences of humankind as something self-evident. Multiple and simultaneous representations of gender, ethnicity and other sociocultural categorizations can function as subtle moral lessons, educating the readers by recognising and encouraging the plurality of voices. Seeing literary study as a means of social change, and seeing texts as performative acts, confirms that cultural artefacts, such as children's literature, can have an input in transforming people's understanding of certain sociocultural categorizations.

It is significant that the different categories are presented to be intersecting and appear simultaneously, with the result that neither gender, nationality, ethnicity nor any other social characteristics are simplified into tight categories. Through these intersecting, overlapping and simultaneous representations of different categories, it is possible to make the stereotyping and labelling visible. When the writers and illustrators show that "the everyday life of Finns" (Havukainen and Toivonen, 2007, 37), or a "normal day in a normal kindergarten" (Widerberg, 2009) contains diversity of ethnicity, 
gender, age, disabilities and so forth, it is influential, despite - or perhaps thanks to - the subtle didacticism. I agree with Eve Bearne who claims that reading children's literature should be seen as a transformative act, as children's books have the power "to transform the here-and-now to what-might-be" (219). In conclusion, I argue that both series offer something more than a mere idea of accepting the Other: the books demonstrate a sense of intercultural awareness, which is based on the insight that a more complex understanding of reality - including children's reality - is needed to make a diverse community an integrated part of society.

As from the Tatu and Patu series as well as the Förskolan Rävlyan series show, picturebooks are influential in conveying cultural values (cf. Cotton 19). The importance of illustration is obvious here; it is the visual narratives that are the most powerful in teaching about other people - people with different cultural values and practices. Additionally, illustrations teach the readers about the diversity in their own cultures, which in terms of the current globalised world is perhaps an even more important lesson to learn. These two series are samples of books which can also challenge some of the traditional, even fixed understandings of social categories, thus creating more inclusive representations of multiculturalism. All in all, children's literature has the potential to be progressive, perhaps even revolutionary, in its capacity to liberate the minds of the readers.

Biographical information: Jaana Pesonen will be defending her PhD in Educational Sciences in 2015. Her research interests include diversity and anti-racism in children's literature, as well as the didacticism of children's books. She is also a lecturer on teacher education and early childhood education degree programs at the University of Oulu, Finland.

\section{Bibliography}

Arizpe, Evelyn. "'All this book is about books' Picturebooks, Culture and Metaliterary Awareness." New Directions in Picturebook Research. Eds. Colomer, Teresa. Kümmerling-Meibauer, Bettina and Silva-Díaz Cecilia. York: Routledge, 2010: 69-82.

Andersen, Margaret. L., and Hill Collins, Patricia. "Conceptualizing Race, Class, and Gender." Race, Class, Gender - An Anthology. Second Edition. Eds. Andersen, Margaret. L. and Hill Collins, Patricia. Belmont: Wadsworth Publishing Company, 1995: 56-70. 
Bearne, Eve. "And what do you think happened next?" Acts of Reading; Teachers, Text and Childhood. Eds. Styles, Morag. and Arizpe, Evelyn. Stoke on Trent: Trentham Books, 2009: 219-231.

Bokprouning: En dokumentation Årgång 2014: 12 mars-28 maj 2015. Stockholm: Svenska barnboksinstitutet, 2015. Web 20 May 2015.

Bonnet, Alastair. Anti-racism. New York: Routledge, 1999.

Botelho, Maria José, and Kabakow Rudman, Masha. Critical Multicultural Analysis of Children's Literature; Mirrors, Windows, and Doors. New York: Routledge, 2009.

Butler, Judith. Bodies that matter - On the discursive limits of "sex". New York/London: Routledge, 1993.

Cotton, Penni. "Visualising Europe through Picture Books: Where are we now?" What do you see? International Perspectives on Children's book illustration. Eds. Harding, Jennifer and Pinset, Pat. Newcastle: Cambridge Scholars Publishing, 2008: 17-34.

Crenshaw, Kimberley. "Demarginalizing the Intersection of Race and Sex: A Black Feminist Critique of Antidiscrimination Doctrine, Feminist Theory, and Antiracist Politics." University of Chicago Legal Forum 14. (1989): 538-54.

Harlin, Rebecca, and Morgan, Hani. "Review of Research: Gender, Racial and Ethnic Misrepresentations in Children's Books: A Comparative Look". Childhood Education 85.3 (2009): 187-190.

Havukainen, Aino, and Toivonen, Sami. Tatu and Patu as superheroes. Helsinki: Otava. 2010 Trans. Owen F. Witesman. Helsinki: Otava, 2007. Originally published as Tatu ja Patu supersanakareina, Helsinki: Otava, 2007.

Havukainen, Aino, and Toivonen, Sami. Tatu and Patu's Oddball Bedtime Book. Helsinki: Otava 2010. Trans. Owen F. Witesman. Originally published as Tatun ja Patun outo unikirja. Helsinki: Otava, 2008.

Havukainen, Aino, and Toivonen, Sami. This is Finland. Trans. Owen F. Witesman. Helsinki: Otava, 2007. Originally published as Tatun ja Patun Suomi, Otava, 2007.

Havukainen, Aino, and Toivonen, Sami. Tatu ja Patu työn touhussa [Tatu and Patu at Work]. Helsinki: Otava, 2006.

Havukainen, Aino, and Toivonen, Sami. Tatu ja Patu päiväkodissa [Tatu and Patu at the Kindergarten]. Helsinki: Otava, 2006. 
Heikkilä-Halttunen, Päivi. "Kuningattaren selluliitti: Suomalaisen sadun teemoja ja mielenmaisemia." Kirjaseikkailu: Lasten- ja nuortenkirjallisuuden opas. Ed. Korolainen, Tuula. Helsinki: Tammi, 2001: 118-237.

Hollindale, Peter. "Ideology and the Children's books".Woodchester: Thimble Press, 1988.

Horne, Jackie C. "Harry and the Other: Answering the race Question in J.K. Rowling's Harry Potter." The Lion and the Unicorn, 34.1 (2010): 76-104.

Lampert, Jo. The whole world shook: Shifts in ethnic, national and heroic identities in children's fiction about 9/11. Queensland University of Technology: Centre for Learning Innovation, 2007.

Laycock, Liz. "A way into a new language and culture." What's in the Picture? Responding to Illustrations in Picture Books. Ed. Evans, Janet. London: Sage Publications, 1998: 79-95.

Lehtonen, Mikko, and Löytty, Olli. "Miksi Erilaisuus?" In Lehtonen, Mikko and Löytty, Olli (eds.) Erilaisuus. Tampere: Vastapaino, 2003: 7-17

McCall, Leslie. "The complexity of Intersectionality." Researching Gender. Volume two. Representation, Voice and Intersectionality. Ed. Hughes, Cristina. London: Sage, 2013: 127-152.

Nikolajeva, Maria. Power, Voice and Subjectivity in Literature for Young readers. New York: Routledge, 2010.

Nikolajeva, Maria, and Scott, Carole. How Picturebooks work. New York: Routledge, 2006.

Pesonen, Jaana. “Nationality in Finnish children's literature - From representations of ethnic difference to representations of culturally diverse society." National identity in picturebooks of the new millennium. Ed. Ommundsen, Åse Marie. Oslo: Novus Press, 2013: 119-132.

Pesonen, Jaana. "Xing, Sikuriina, Tatu ja Patu: Monimuotoinen monikulttuurisuus 2000-luvun lastenkirjoissa." (Xing, Sikuriina, Tatu and Patu: Diverse Multiculturalism in 21st Century Children's Books). Kaikille lapsille. Lastenkirjallisuus liikkuvassa, monikulttuurisessa maailmassa. Ed. Rastas, Anna. Helsinki: Suomalaisen Kirjallisuuden Seura, 2013: 62-82.

Pesonen, Jaana. “Anti-racist Strategies in Finnish Children's Literature: Physical Appearance and Language as Signifiers of National Belonging." Children's Literature in Education, 44. 3. (2013): 238-250. 
Pesonen, Jaana. "Etnisen erilaisuuden kuvauksia 1900-luvun suomalaisessa lastenkirjallisuudessa - Erilaisuuden diskurssi: mystifiointia, romantisoimista ja holhoamista" (Descriptions of Ethnic Diversity in 20th century Finnish Children's Literature - Discourse of Difference: Mystifying, Romanticizing and Patronising). Education, ethics and global responsibility. Publication in honor of Professor Rauni Räsänen. Eds. Järvelä, Maria-Liisa, Ritola, Laura and Sitomaniemi-San, Johanna. Oulu: Oulu university press. 2010: 113-128.

Sands-O'Connor, Karen. "Why are people different? Multiracial families in picture books and the dialogue of difference." The Lion and The Unicorn, 25. (2001): 412-426.

Stephens, John. "Schemas and Scripts: Cognitive Instruments and the Representation of Cultural Diversity in Children's Literature." Contemporary Children's Literature and Film. Engaging with Theory. Eds. Mallan, Kerry and Bradford, Clare. New York: Palgrave Macmillan, 2011: 12-35.

Stephens, John. "Preface." Ways of Being Male. Representing Masculinities in Children's Literature and Film. Ed. Stephens, John. New York. Routledge, 2002: ix-xiv.

Stephens, John. Language and Ideology in Children's Fiction. New York: Longman Publishing, 1992.

Miettinen, Anneli. "Maahanmuuttajien mä̈rä." Väestöliitto/Population Research Institute. Web. 6 May 2014.

Westin, Boel. Children's literature in Sweden. Stockholm: The Swedish Institute, 1991.

Westin, Charles. "Sweden: Restrictive Immigration Policy and Multiculturalism." Migration Policy Institute, 1 June 2006. Web. 8 May 2014.

Widerberg, Siv. Moa och Samir - de nya stövlarna [Moa and Samir The new shoes]. (Illustration Mati Lepp). Stockholm: Rabén \& Sjögren, 2013.

Widerberg, Siv. Moa och Samir i lekparken [Moa and Samir at the playground]. (Illustration Mati Lepp). Stockholm: Rabén \& Sjögren, 2013.

Widerberg, Siv. Förskolan Rävlyan - Ojdå! [Kindergarten Fox Earth - Oh Dear!]. (Illustration Cecilia Torudd). Stockholm: Rabén \& Sjögren, 2009. 
Widerberg, Siv. Förskolan Rävlyan - Kolla! [Kindergarten Fox Earth - Look!] (Illustration Cecilia Torudd). Stockholm: Rabén \& Sjögren, 2009.

Widerberg, Siv. Stolar, Stolar, Stolar. [Chairs, Chairs, Chairs] (Illustration Cecilia Torudd). Stockholm: Eriksson \& Lindgren, 2003.

Widerberg, Siv. Snö, Snö, Snö [Snow, Snow, Snow] (Illustration Cecilia Torudd). Stockholm: Eriksson \& Lindgren, 2004.

Woodward, Kathryn. "Concepts of Identity and Difference." Identity and Difference: Culture, Media and Identities. Ed. Woodward, Kathryn. London: Sage, 1997: 8-50.

Österlund, Mia. "Att formge en flicka. Flickskapets transformationer hos Pija Lindenbaum och Stina Wirsén." In Flicktion: perspektiv på flickan i fiktionen. Eds. Söderberg, Eva. Österlund, Mia and Formark, Bodil. Malmö: Universus Academic Press, 2013: 168-187.

Österlund, Mia, Lassén-Seger, Maria, and Franck, Mia. “'Glokal' litteraturhistoria: på väg mot en omvärdering av finlandssvensk barnlitteratur." Nordic Journal of ChildLit Aesthetics, 34. 1. (2010): 60-71.

\section{Notes}

1 Finland and Sweden have implemented quite different polices related to asylum seekers and immigrants, at least in terms of numbers: in 20001.8 percent of Finland's population was foreign born, while in Sweden this was 11.3 percent. Finland and Sweden also have a shared history related to immigration, as during the WWII around 70000 children were sent from Finland to Sweden as evacuees, and later (1940s-1970s) Sweden received many labor immigrants from Finland. In addition, the biggest immigrant group in Sweden still is Finnish people (statistics from Väestöliitto [The Family Federation of Finland] and C. Westin, 2006).

2 All other book names and text samples, except for This is Finland (2007), have been translated into English by the researcher.

3 Widerberg has also written the Moa och Samir series (2013), in which multiculturalism is present in a non-explicit manner. Additionally, Widerberg's picturebooks for younger readers, for example Snö, Snö, Snö (Snow, Snow, Snow, 2004) and Stolar, Stolar, Stolar (Chairs, Chairs, Chairs, 2003) include diversity as part of the story. 